\title{
Beauveriabassiana, a Biocontrol Agent against the Red Palm Weevil, RhynchophorusFerrugineus Larvae under Laboratory and Field Conditions.
}

\author{
Ahmed, A. Bardan; Naglaa, F. Abdel- Hameid"; Adel,A. Hafež and Fawzy. F. Shalaby* \\ * = M. Sc. Student, Plant Protection Dept., Faculty of Agriculture, Benha University \\ ${ }_{* *}^{*}=$ Plant Protection Department, Faculty of Agriculture, Benha University
}

\begin{abstract}
The presented study was carried out to assay the efficacy of a Beauveriabassiana(Balsamo) Vuillemincommercial formulation (Newfar) and its isolates against larvae of the red palm weevil Rhynchophorusferrugineus(Olivier). Bioassay experiments took place to estimate theLC $\mathrm{L}_{50}, \mathrm{LC}_{90}, \mathrm{LT}_{50}$ and $\mathrm{LT}_{90}$ values. By Newfar treatment, theLC $\mathrm{C}_{50}$ 's against the $1^{\text {st }}, 5^{\text {th }}$ and $10^{\text {th }}$ larval instars of $R$. ferrugineus were 0.078 , 0.192 and $0.406 \mathrm{~g} / \mathrm{ml}$, respectively. $\mathrm{LC}_{90}$ values were $0.610,2.030$ and $4.547 \mathrm{~g} / \mathrm{ml}$, respectively for the $1^{\text {st }}, 5^{\text {th }}$ and $10^{\text {th }}$ instarafter 25 days of treatment. Also, the $\mathrm{LT}_{50}$ values after using the concentration $1 \times 10^{8} \mathrm{CFU}$ 's $/ 100 \mathrm{mlwere}$ 14.549, 16.167 and 21.022, days, respectively, while those of $\mathrm{LT}_{90}$ were23.374, 31.196 and 99.344 days, respectively. Whereas, $1 \times 10^{8} \mathrm{CFU}$ 's $/ 100 \mathrm{ml}$ caused $95 \%$ mortality for $1^{\text {st }}$ instar, $85 \%$ for $5^{\text {th }}$ instar, and $65 \%$ for $10^{\text {th }}$ instar, 25 days after treatment. The concentration $28 \times 10^{6}$ conidia / $100 \mathrm{ml}$ caused $85 \% 65 \%$ and $55 \%$ mortality for $1^{\text {st }}, 5^{\text {th }}$ and $10^{\text {th }}$ instar, respectively 25 days post-treatment. Additionally, five concentrations of both commercial formulation and isolates of conidial spores ( 1 x $10^{8} \mathrm{CFU}$ 's / 100ml and $28 \times 10^{6}$ conidia / 100ml) were evaluated against the $1^{\text {st }}, 5^{\text {th }}$ and $10^{\text {th }}$ larval instars of red palm weevil under laboratory and field conditions. The results revealed that mortalities among treated larvae were significantly different than control, where no larva died among the control treatments. The current study confirmed that the lethal action of B. bassiana was directly proportional to the spore's concentration. This study further confirmed that the earlier larval instars was more affected by $B$. bassiana treatments than older ones.
\end{abstract}

The field study showed that infested date palm trees injected by New far formulation (B. bassiana) at the site of infestation by the red palm weevil caused $80 \%$ recovery from infestation after 25 days from treatment.

Key word: Bioassay, Red palm weevil, Beauveriabassiana.

\section{Introduction}

The red palm weevil (RPW) Rhynchophorusferrugineus (Olivier) Coleoptera: Curculionidae) causes large economic losses in cultivated palms worldwide (Murphy and Briscoe, 1999; Faleiro, 2006and Wakilet al., 2015). It causes yield losses from $0.7-10$ tons/ha(Singh and Rethinam, 2005).Also, its distribution is reported in Oceania, Asia, Africa and Europe and was found in Curaçao and Marruecos in 2008, and USA in 2010 (EPPO, 2010). It affects a wide range of palms (Dembilio andJaques, 2015) including economically important species such as the date palm (Phoenix dactylifera L.), Canary Islands date palm ( $P$. canariensis Hort.), coconut (CocosnuciferaL.), African oil palm (ElaeisguineensisJacq.) and chusan palm (Trachycarpusfortunei) (Hook.).

Intensive chemical control caused the evolution of insects'resistance, residue persistence, hazards to employees and to the environment and harm to nontarget organisms have urged researchers to explore safe alternatives for RPW control (Hussain et al., 2013andJalinaset al., 2015). The biological control agents involving entomopathogenic bacteria, fungi and nematodes were laboratory assayed for control of this pest (Salamaet al., 2004; Manachini et al., 2009; Dembilioet al., 2010;El-Hindi, 2016 and Muhammad et al., 2019).
To improve management options against the weevil, the efficacy of the entomopathogenic nematode Steinernemacarpocapsae Weiser (Nematoda: Steinernematidae) and the potential of the entomopathogenicstrain of the fungus Beauveriabassiana(Ascomycota: Clavicipitaceae) were evaluated in laboratory, semi-field and field assays by Dembilio and Jaques, (2013). The use of these entomopathogenic microorganisms proved highly efficient against $R$. ferrugineus. Also, Muhammad et al., (2019) confirmed that the isolates recovered from $R$. ferrugineus dead cadavers gave higher mortality rates compared to the other sources. In order to ensure safe control of RPW, the present study was carried out to assay the effectiveness of $B$. bassiana(either its commercial product, namely Newfar) or the recovered isolates of fungi from different dead larval instars of $R$. ferrugineusin laboratory. The efficacy of New far against this insectpest in the field was, also, evaluated. It is hoped that this study could add a new beam of light for better understanding the use of entomopathogic fungi for the RPW control.

\section{Materials and Methods}

Collection and rearing of red palm weevil (RPW) Males and females of red palm weevil (R. ferrugineus) were collected from date palm groves in $\mathrm{Al}$ 
Qassaseen, Ismailia Governorate, Egypt during 2018. Collected adults were bred on pieces of sugar cane stems. The females laid eggs below the upper surface of the sugar cane slices. Deposited eggs were separated by a fine brush and transferred into Petridishes containing a filter paper wetted with water. Freshly hatched larvae were reared on pieces of sugar cane stems, and the dissection process of sugar cane stems was monitored until pupation inside the cocoon still emergence of insect adults.

Rearing of RPW occurred under $27 \pm 2{ }^{\circ} \mathrm{C}$ and $70 \pm$ $2 \%$ R.H. in the insectary of Insect Biology, Plant Protection Department., Faculty of Agriculture, Benha University.

\section{The bio insecticide}

The commercial bio-insecticide New faris produced by the Pesticide Production Unit of the Plant Protection Research Institute at Dokki. This product contains the entomopathogenic fungi, B. bassianaat a concentration of $1 \times 10^{8} \mathrm{CFU}$ 's / $\mathrm{mg}$ for insect control. Therecommended concentration to be applied is $10 \mathrm{gm}$ / $1 \mathrm{~L}$ of water.

\section{Bioassay experiments with New farversus larvae of RPW}

In order to investigate the efficacy of the commercial formulation Newfar to control red palm weevil,three larval instars (first, fifth and tenth) of red palm weevil were treated with five concentrations $\left[1 \times 10^{8}, 0.5 \times 10^{8}, 0.25 \times 10^{8}, 0.125 \times 10^{8}\right.$ and $0.0625 \times 10^{8}$ CFU's $/ 100 \mathrm{ml}$ distilled water].Each concentration was replicated five times, four larvae from each instar / replicate, i.e. a total of 20 larvae / treatment. Treated larvae and those of the control were checked daily and mortalities were recorded for 25 days. The concentrations were prepared in half-life way, where a volume of $2 \mathrm{ml}$ of the suspension were added to $10 \mathrm{gm}$ of grated sugar cane plant for treatment of the first instar; $5 \mathrm{mlwere}$ added to $15 \mathrm{gm}$ of grated sugar canefor the $5^{\text {th }}$ larval instar and $10 \mathrm{ml}$ were distributed on $25 \mathrm{gm}$ of grated sugar cane for the $10^{\text {th }}$ larval instar treatment. Subsequently, the first instar larvae were kept in glass bottles $(3 \mathrm{~cm}$ diameter and $7 \mathrm{~cm}$ height)with treated diet and covered with cotton cope to allow respiration of larvae, while larvae of the $5^{\text {th }}$ and $10^{\text {th }}$ instarswere kept in small jars $(5 \mathrm{~cm}$ diameter and $10 \mathrm{~cm}$ height)contained noted weight of treated sugar cane pieces and covered by perforated metal cover for respiration. Larvae in each treatment were checked daily and the larvae that showed no movement were considered dead. With every inspection date, the number of dead larvae was counted and recorded.

Also, the dead larvae were collected, placed in sterile Petri-dishes with $75-80 \%$ humidity and incubated at $30 \pm 1{ }^{\circ} \mathrm{C}$ in order to retrieve fungal spores, to be used later in the needed experiment.

\section{Fungal isolates against larvae of RPW}

B.bassiana isolates were obtained from laboratory infected RPW larvae collected from the above mentioned experiment. All the dead cadavers of RPW were placed in sterile dishes with $75-80 \%$ humidity and incubated at $30 \pm 1{ }^{\circ} \mathrm{C}$ for a period of seven days until the appearance of any fungal outgrowths and spores, then spores were transferred to Petri-dishes containing Sabouraud Dextrose Agar (SDA). The plates were incubated at $30 \pm 1{ }^{\circ} \mathrm{C}$.

When more than one fungal colony were present on the medium, the colonies at the age of 10 days were suspended in $100 \mathrm{ml}$ of distilled water containing $2 \mathrm{ml}$ of the Tween solution $2.0 \%$, then the concentration of spores was calculated using a specific slide under the microscope. The conidial concentration of the suspension was $28 \times 10^{6}$ Conidia / ml. Five conidial concentrations $\left[1 \%\left(28 \times 10^{6}\right), 0.5 \%\left(14 \times 10^{6}\right), 0.25 \%\right.$ $\left(7 \times 10^{6}\right), 0.125 \%\left(3.5 \times 10^{6}\right)$ and $0.0652 \%\left(1.75 \times 10^{6}\right)$ conidia $/ 100 \mathrm{ml}$ ]were added each to $100 \mathrm{ml}$ of distilled water to be assayed against $1^{\text {st }}, 5^{\text {th }}$ and $10^{\text {th }}$ instar larvae. The treatment was performed with the same sequence and under the same conditions that were used in the previous experiment. The control individuals were treated with only distilled water. Each replicate consisted of four individuals and five replicates in each treatment. A total of 20 larvae / treatment were used. Mortalities among larvae were checked daily for 25 days and no corrected mortality percentages were needed due to zero mortality among all the control replicates.

\section{B. bassiana treatment against red palm weevil in the field}

These treatments were performed upon occurrence of infestation by RPW to palm trees at Al Kassasen region in Ismailia Governorate in 2019. Five RPW infested palm trees were randomly chosen in the field, each represented one replicate for this experiment. The fungal suspension was prepared at one concentration (10g Newfar / liter of water) $\left(1 \times 10^{8}\right.$ CFU's/mg)in each injection. The bioinsecticide was applied through the holes which were made around the site of infestation using a large iron pin then injected by the fungicide using plastic piping (Plate 1). Trees received the same treatment 7 days after the first one. The chosen date palm trees were inspected for evaluation of injury after 10, 15, 20 and 25 days after the date of the first application by skimming and cleaning the affected places looking for the dead RPW individuals in all its stages. 


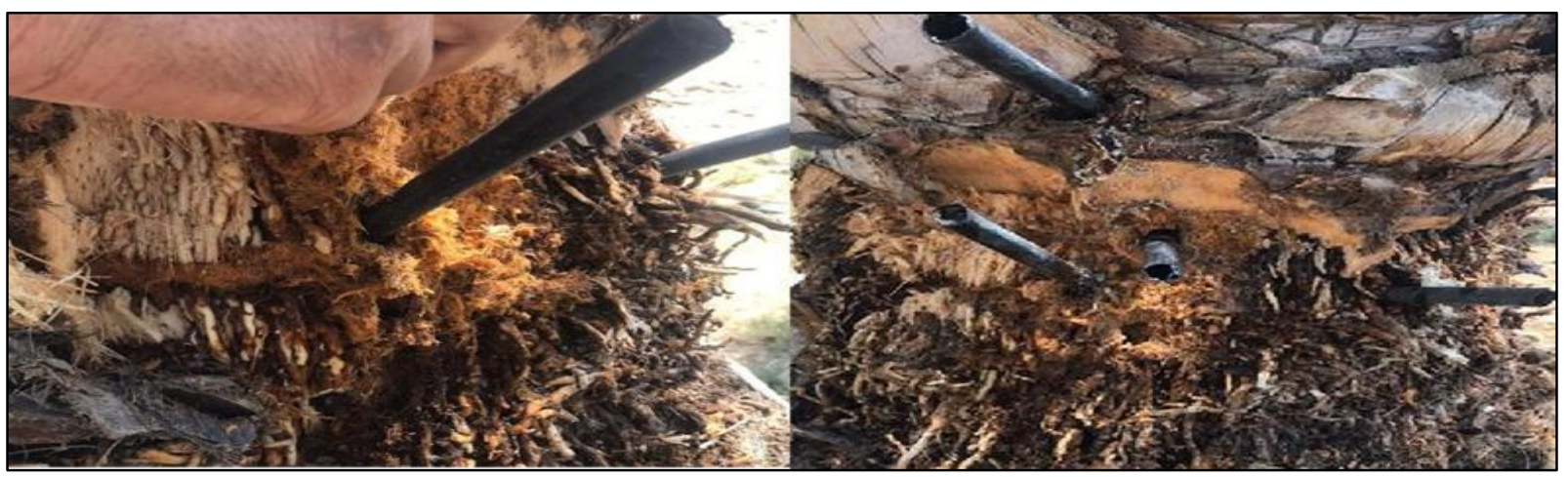

Plate (1): Injection method of $B$. bassiana formulation ininfested date palmtrees in the field.

Statistical analysis:

Cumulative mortality at the end of the experiment was analyzed by ANOVA. The concentration scausing 50 and $90 \%$ mortalities, $\left(\mathrm{LC}_{50} \& \mathrm{LC}_{90}\right)$ and time needed for causing 50 and $90 \%$ cumulative mortalities $\left(\mathrm{LT}_{50}\right.$ $\& \mathrm{LT}_{90}$ ) were determined using the probit analysis program LPD-line(Bakr, 2005)

Results and Discussion
Bioassay of Newfar (commercial product of $B$. bassiana) versus larvae of RPW

Results in Table (1) and Fig.(1)show the mortality percentages among RPW larvae after 5,10,15,20 and 25 days post treatment. The first instar larvae of RPW were highly susceptible to $B$. bassiana, where the assayed concentrations caused 95\%, 85\%, 80\%,60\% and $45 \%$ mortality after 25 days post treatment with $1 \times 10^{8}, \quad 0.5 \times 10^{8}, \quad 0.25 \times 10^{8}, \quad 0.125 \times 10^{8}$ and $0.0625 \times 10^{8}$ CFU's / $100 \mathrm{ml}$ water, respectively.

Table 1. Mean cumulative mortality percentages among larvae of $R$. ferrugineus treated with different concentrations of commercial product of B. bassiana (total number of 20 larvae / treatment).

Time of inspection after treatment on

1st larval instar

\begin{tabular}{|c|c|c|c|c|c|c|c|c|c|c|}
\hline \multirow{2}{*}{$\begin{array}{l}\text { Concentration } \\
\text { (CFU's/100ml) }\end{array}$} & \multicolumn{2}{|c|}{5 days } & \multicolumn{2}{|c|}{10 days } & \multicolumn{2}{|c|}{15 days } & \multicolumn{2}{|c|}{20 days } & \multicolumn{2}{|c|}{25 days } \\
\hline & Mean & $\%$ & Mean & $\%$ & Mean & $\%$ & Mean & $\%$ & Mean & $\%$ \\
\hline $1 \times 10^{8}$ & 0 & 0 & 0.8 & $20 \%$ & 1.6 & $40 \%$ & 3.2 & $80 \%$ & 3.8 & $95 \%$ \\
\hline $0.5 \times 10^{8}$ & 0 & 0 & 0.8 & $20 \%$ & 1.4 & $35 \%$ & 1.6 & $40 \%$ & 3.4 & $85 \%$ \\
\hline $0.25 \times 10^{8}$ & 0.6 & $15 \%$ & 0.8 & $20 \%$ & 1.8 & $45 \%$ & 2.4 & $60 \%$ & 3.2 & $80 \%$ \\
\hline $0.125 \times 10^{8}$ & 0 & 0 & 0.2 & $5 \%$ & 1.6 & $40 \%$ & 2.2 & $55 \%$ & 2.4 & $60 \%$ \\
\hline $0.0625 \times 10^{8}$ & 0 & 0 & 0.2 & $5 \%$ & 0.8 & $20 \%$ & 1.6 & $40 \%$ & 1.8 & $45 \%$ \\
\hline Control & 0 & 0 & 0 & 0 & 0 & 0 & 0 & 0 & 0 & 0 \\
\hline \multicolumn{11}{|c|}{ 5th larval instar } \\
\hline Concentration & \multicolumn{2}{|c|}{5 days } & \multicolumn{2}{|c|}{10 days } & \multicolumn{2}{|c|}{15 days } & \multicolumn{2}{|c|}{20 days } & \multicolumn{2}{|c|}{25 days } \\
\hline (CFU's/100ml) & Mean & $\%$ & Mean & $\%$ & Mean & $\%$ & Mean & $\%$ & Mean & $\%$ \\
\hline $1 \times 10^{8}$ & 0 & 0 & 0.8 & $20 \%$ & 1.6 & $40 \%$ & 2.4 & $60 \%$ & 3.4 & $85 \%$ \\
\hline $0.5 \times 10^{8}$ & 0 & 0 & 0 & 0 & 0.8 & $20 \%$ & 1.8 & $45 \%$ & 2.4 & $60 \%$ \\
\hline $0.25 \times 10^{8}$ & 0.8 & $20 \%$ & 1 & $25 \%$ & 1.4 & $35 \%$ & 2.2 & $55 \%$ & 2.4 & $60 \%$ \\
\hline $0.125 \times 10^{8}$ & 0 & 0 & 0 & 0 & 0 & 0 & 1.6 & $40 \%$ & 1.8 & $45 \%$ \\
\hline $0.0625 \times 10^{8}$ & 0 & 0 & 0 & 0 & 0.6 & $15 \%$ & 0.8 & $20 \%$ & 1 & $25 \%$ \\
\hline Control & 0 & 0 & 0 & 0 & 0 & 0 & 0 & 0 & 0 & 0 \\
\hline \multicolumn{11}{|c|}{ 10th larval instar } \\
\hline \multirow{2}{*}{$\begin{array}{l}\text { Concentration } \\
\text { (CFU's/100ml) }\end{array}$} & \multicolumn{2}{|c|}{5 days } & \multicolumn{2}{|c|}{10 days } & \multicolumn{2}{|c|}{15 days } & \multicolumn{2}{|c|}{20 days } & \multicolumn{2}{|c|}{25 days } \\
\hline & Mean & $\%$ & Mean & $\%$ & Mean & $\%$ & Mean & $\%$ & Mean & $\%$ \\
\hline $1 \times 10^{8}$ & 0.6 & $15 \%$ & 0.8 & $20 \%$ & 1.4 & $35 \%$ & 1.8 & $45 \%$ & 2.6 & $65 \%$ \\
\hline $0.5 \times 10^{8}$ & 0.8 & $20 \%$ & 1 & $25 \%$ & 1.4 & $35 \%$ & 2 & $50 \%$ & 2.4 & $60 \%$ \\
\hline $0.25 \times 10^{8}$ & 0 & 0 & 0.6 & $15 \%$ & 0.8 & $20 \%$ & 1.4 & $35 \%$ & 1.6 & $40 \%$ \\
\hline $0.125 \times 10^{8}$ & 0 & 0 & 0 & 0 & 0 & 0 & 0.8 & $20 \%$ & 1 & $25 \%$ \\
\hline $0.0625 \times 10^{8}$ & 0 & 0 & 0 & 0 & 0 & 0 & 0 & 0 & 0 & 0 \\
\hline Control & 0 & 0 & 0 & 0 & 0 & 0 & 0 & 0 & 0 & 0 \\
\hline
\end{tabular}




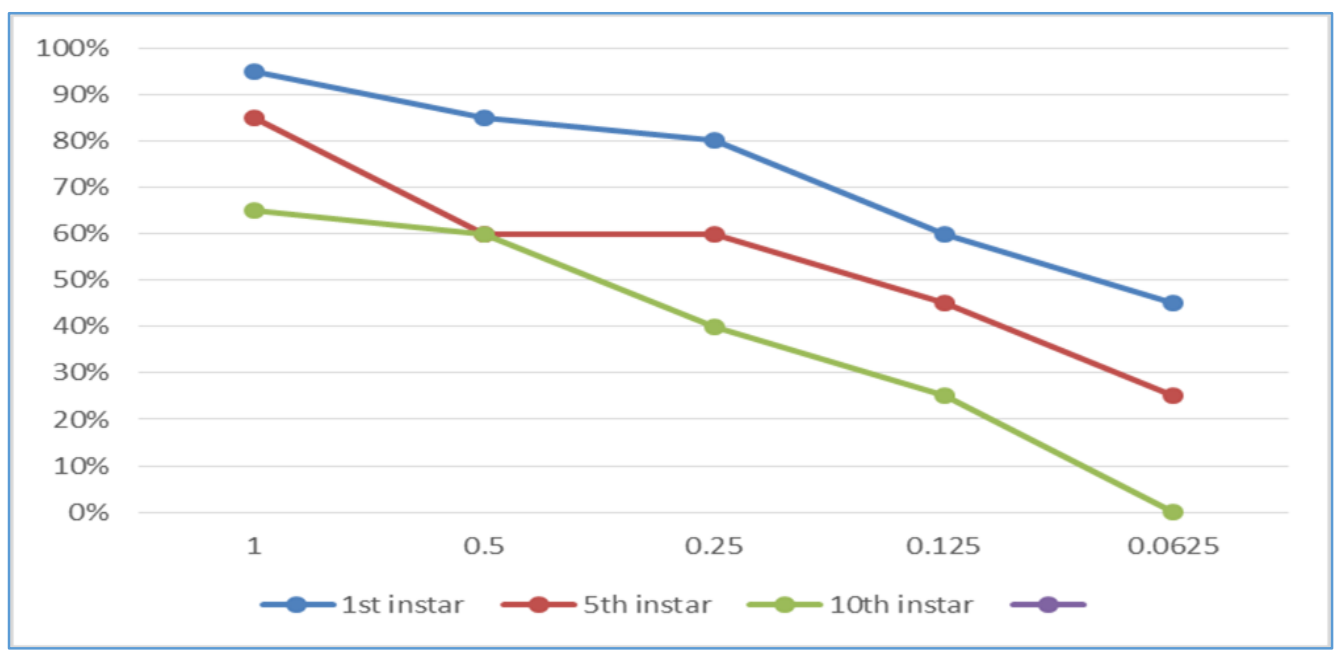

Fig. (1): Mean cumulative mortality percentages among $R$. ferrugineus larvae treated with commercial product of $B$. bassiana (at different concentratione), 25days after treatment.

That was followed by the fifth larval instar which recorded $85,60,60,45$, and $25 \%$ mortality after 25 days post treatment. While, the $10^{\text {th }}$ larval instar recorded the lowest mortality percentages with most concentrations after 25 days post-treatment $(65,60$, 40,25 and $0.0 \%$ ), respectively. Thus, indicating that the lowest concentration was, completely, ineffective on the $10^{\text {th }}$ instar larvae. The lowest percentages of mortality were recorded for treatments by the lowest concentration $\left(0.0625 \times 10^{8} \mathrm{CFU}\right.$ 's / $100 \mathrm{ml}$ water $)$ in most post-treatment periods.

Cumulative mortality reached maximum values 25 days after treatment (Table, 1 and Fig. 1). No control larvae died among either of the concerned three instars. Also, mortality caused by commercial product of $B$. bassiana was lower for $10^{\text {th }}$ than for $1^{\text {st }}$ and $5^{\text {th }}$ larval instars. In this respect, Malik et al., 2019 investigated the effect of B. bassiana $\left(1.8 \times 10^{7}\right.$ and $1.8 \times 10^{8}$ conidia $/ \mathrm{ml}$ ) alone and in combination against fifth and sixth larval instars of $R$. ferrugineus. The insects were exposed to fungal treatments by diet incorporation method. Results revealed that the application of $B$. bassiana at the rate of $\left(1.8 \times 10^{8}\right.$ conidia/ml) exhibited synergistic effect, Moreover, the mortality data showed that fifth instar larvae were more susceptible to microbial treatments than sixth instar.

Toxicity ( $\mathrm{LC}_{50} \& \mathrm{LC}_{90}$ and $\mathrm{LT}_{50} \& \mathrm{LT}_{90}$ ) of Newfar (commercial product of $B$. bassiana) against RPW larvae

The lethal concentrations $\mathrm{LC}_{50} \& \mathrm{LC}_{90}$ recorded at 5, $10,15,20$ and 25 days after treatment of RPW larvae for $1^{\text {st }}, 5^{\text {th }}$ and $10^{\text {th }}$ instarswere assessed (Table, 2 and Fig. 2). The three tested larval instars behaved differently in toxicity. Considering $1^{\text {st } l a r v a l ~ i n s t a r, ~ i t ~}$ was the most affected,followed by $5^{\text {th }}$ instar and finally $10^{\text {th }}$ instar which manifested lowest mortality percentage. The recorded $\mathrm{LC}_{50}$ values, 25 days posttreatment were $0.078,0.192$ and 0.406 , respectively.Consequently, the $\mathrm{LC}_{90}$ values were $0.610,2.030$ and 4.547, respectively. Also, it could be easily noticed that the $\mathrm{LC}_{50}$ and $\mathrm{LC}_{90}$ values of the product's concentration increased as the treated larvae grew elder.

Table 2. Toxicity (Lethal concentration) of commercial product of $B$. bassiana tested against larval instars of $R$. ferrugineus.

\begin{tabular}{cccc}
\hline Larval instar & LC $_{50}(\mathrm{~g} / \mathrm{ml})^{*}$ & LC $_{90}(\mathrm{~g} / \mathrm{ml})^{*}$ & Slope \pm SE \\
\hline \multirow{2}{*}{$1^{\text {st }}$} & 0.078 & 0.610 & $1.436 \pm 0.142$ \\
& $0.041 \pm 0.148$ & $0.321 \pm 1.159$ & \\
$5^{\text {th }}$ & 0.192 & 2.030 & $1.263 \pm 0.148$ \\
& $0.098 \pm 0.374$ & $1.040 \pm 3.963$ & 4.547 \\
$1^{\text {th }}$ & 0.406 & $2.275 \pm 9.088$ & $1.225 \pm 0.153$ \\
\hline
\end{tabular}

*Results were calculated after 25 days of treatment.

The days spent till insect mortality are calculated at 50 and $90 \%$ mortalities, $\left(\mathrm{LT}_{50} \& \mathrm{LT}_{90}\right)$ which were calculated for the treated larvae at a Newfar concentration of $1 \times 10^{8} \mathrm{CFU}$ 's / $100 \mathrm{ml}$. As shown in (Table, 3 and Fig. 3), death of the $1^{\text {st }}$ instar took the shortest time, then the $5^{\text {th }}$ and the $10^{\text {th }}$ instars. Results indicated that the $\mathrm{LT}_{50}$ 's were $14.549,16.167$ and 21.022 days, respectively, opposed to $23.374,31.196$ and 99.344 days, for the $\mathrm{LT}_{90}$ for the $1^{\text {st }}, 5^{\text {th }}$ and $10^{\text {th }}$ larval instars, respectively. 

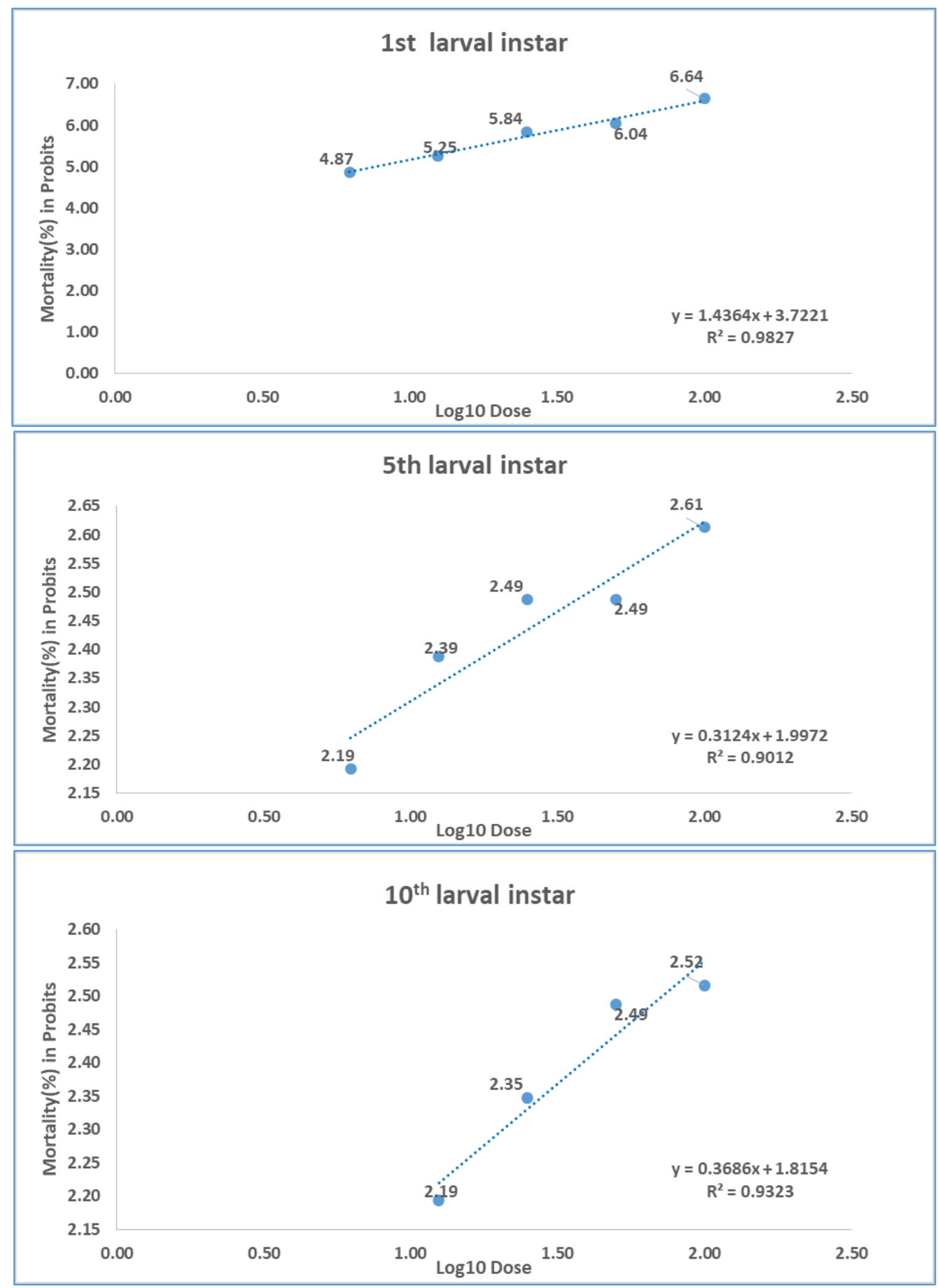

Fig.(2): Toxicity (Lethal concentration) of Newfar(B. bassiana) tested against larval instars of R. ferrugineus. 


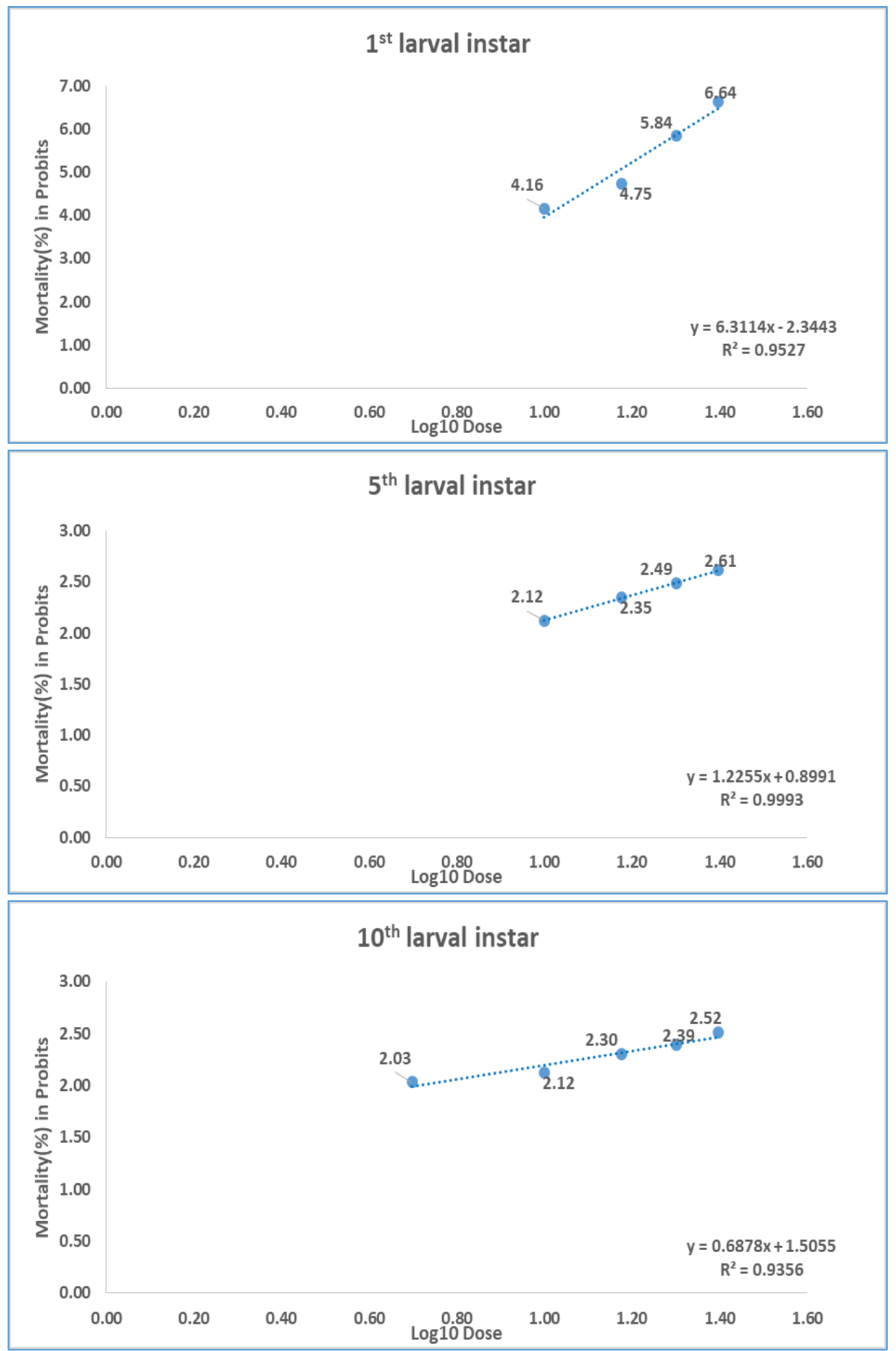

Fig.(3): Toxicity (Lethal time) of Newfar(B. bassiana) tested against larval instars of $R$. ferrugineus. 
Table 3. Toxicity (Lethal time) of commercial product of $B$. bassiana tested against larval instars of $R$. ferrugineus. Results were calculated using concentration $1 \mathrm{gm} / 100 \mathrm{ml}$.

\begin{tabular}{|c|c|c|c|}
\hline Larval instar & $\mathbf{L T}_{50}$ ( days) & LT90 (days) & Slope \pm SE \\
\hline $1^{\text {st }}$ & $\begin{array}{c}14.549 \\
12.314 \pm 17.190\end{array}$ & $\begin{array}{c}23.374 \\
19.783 \pm 27.616\end{array}$ & $6.311 \pm 0.037$ \\
\hline $5^{\text {th }}$ & $\begin{array}{c}16.167 \\
13.103 \quad \pm 19.947\end{array}$ & $\begin{array}{cc}31.196 \\
25.283 \quad \pm 38.490\end{array}$ & $4.534 \pm 0.047$ \\
\hline $10^{\text {th }}$ & $\begin{array}{cc}21.022 \\
13.537 \quad \pm 32.646\end{array}$ & \begin{tabular}{cc}
\multicolumn{2}{c}{99.344} \\
63.971 & 154.277
\end{tabular} & $1.935 \pm 0.098$ \\
\hline
\end{tabular}

Pathogenicity of the entomopathogenic fungus, B.bassiana against R.ferrugineus was studied by ElSuftyet al., (2009)in United Arab Emiratesusing a local strain "UAE-B2". In agreement with present results, they and El Husseini (2019) found that the young instars of larvae were more susceptible than the older ones. El- Suftyet al., (2009) added that in adult and larval stages, the fungus remains dormant inside the cadavers and started to continue its saprophytic development when R.H. approached $100 \%$. The same authors estimated that complete mycosed cadaver produced $4.3 \times 10^{7}$ conidia.

Effect of a conidial suspension $\left(28 \times 10^{6}\right.$ conidia / 100 $\mathrm{ml}$ sterile distilled water) of fungal isolate from RPW dead larvae

Results in (Table, 4 and Fig.4) show that cumulative

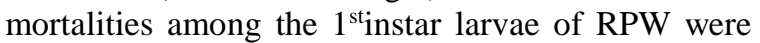
$85,60,40,25$ and $20 \%$, opposed to $65,60,40,40$ and $20 \%$ among larvae of the $5^{\text {th }}$ instar at 25 days post treatment by the $28 \times 10^{6}, 14 \times 10^{6}, 7 \times 10^{6}, 3.5 \times 10^{6}$ and $1.75 \times 10^{6}$ conidia $/ 100 \mathrm{ml}$, respectively.

Table 4. Mean cumulative mortality percentages among $R$. ferrugineuslarvae treated with conidial suspension $\left(28 \times 10^{6}\right.$ spores / $\left.100 \mathrm{ml}\right)$ of fungal isolate.

Time of inspection after treatment on

1st larval instar

\begin{tabular}{|c|c|c|c|c|c|c|c|c|c|c|}
\hline \multirow{2}{*}{$\begin{array}{l}\text { Concentration } \\
\text { (conidia/100ml) }\end{array}$} & \multicolumn{2}{|c|}{5 days } & \multicolumn{2}{|c|}{10 days } & \multicolumn{2}{|c|}{15 days } & \multicolumn{2}{|c|}{20 days } & \multicolumn{2}{|c|}{25 days } \\
\hline & Mean & $\%$ & Mean & $\%$ & Mean & $\%$ & Mean & $\%$ & Mean & $\%$ \\
\hline $28 \times 10^{6}$ & 0 & 0 & 1 & $25 \%$ & 1.2 & $30 \%$ & 2.6 & $65 \%$ & 3.4 & $85 \%$ \\
\hline $14 \times 10^{6}$ & 0.6 & $\begin{array}{l}15 \\
\%\end{array}$ & 0.8 & $20 \%$ & 1.8 & $45 \%$ & 2 & $50 \%$ & 2.4 & $60 \%$ \\
\hline $7 \times 10^{6}$ & 0.2 & $5 \%$ & 0.4 & $10 \%$ & 0.8 & $20 \%$ & 1 & $25 \%$ & 1.6 & $40 \%$ \\
\hline $3.5 \times 10^{6}$ & 0 & 0 & 0 & 0 & 0.8 & $20 \%$ & 1 & $25 \%$ & 1 & $25 \%$ \\
\hline $1.75 \times 10^{6}$ & 0 & 0 & 0 & 0 & 0.6 & $15 \%$ & 0.8 & $20 \%$ & 0.8 & $20 \%$ \\
\hline Control & 0 & 0 & 0 & 0 & 0 & 0 & 0 & 0 & 0 & 0 \\
\hline \multicolumn{11}{|c|}{ 5th larval instar } \\
\hline \multirow{2}{*}{$\begin{array}{c}\text { Concentration } \\
\text { (conidia/100ml) }\end{array}$} & \multicolumn{2}{|c|}{5 days } & \multicolumn{2}{|c|}{10 days } & \multicolumn{2}{|c|}{15 days } & \multicolumn{2}{|c|}{20 days } & \multicolumn{2}{|c|}{25 days } \\
\hline & Mean & $\%$ & Mean & $\%$ & Mean & & Mean & $\%$ & Mean & $\%$ \\
\hline $28 \times 10^{6}$ & 0 & 0 & 1 & $25 \%$ & 2.4 & $60 \%$ & 2.4 & $60 \%$ & 2.6 & $65 \%$ \\
\hline $14 \times 10^{6}$ & 0.8 & $\begin{array}{l}20 \\
\%\end{array}$ & 1 & $25 \%$ & 1.6 & $40 \%$ & 1.8 & $45 \%$ & 2.4 & $60 \%$ \\
\hline $7 \times 10^{6}$ & 0 & 0 & 0.6 & $15 \%$ & 0.8 & $20 \%$ & 1.4 & $35 \%$ & 1.6 & $40 \%$ \\
\hline $3.5 \times 10^{6}$ & 0 & 0 & 0 & 0 & 0.8 & $20 \%$ & 1 & $25 \%$ & 1.6 & $40 \%$ \\
\hline $1.75 \times 10^{6}$ & 0 & 0 & 0 & 0 & 0 & 0 & 0 & 0 & 0.8 & $20 \%$ \\
\hline \multirow[t]{2}{*}{ Control } & 0 & 0 & 0 & 0 & 0 & 0 & 0 & 0 & 0 & 0 \\
\hline & \multicolumn{6}{|c|}{ 10th larval instar } & & & & \\
\hline \multirow{2}{*}{$\begin{array}{l}\text { Concentration } \\
\text { (conidia/100ml) }\end{array}$} & \multicolumn{2}{|c|}{5 days } & \multicolumn{2}{|c|}{10 days } & \multicolumn{2}{|c|}{15 days } & \multicolumn{2}{|c|}{20 days } & \multicolumn{2}{|c|}{25 days } \\
\hline & Mean & $\%$ & Mean & $\%$ & Mean & & Mean & $\%$ & Mean & $\%$ \\
\hline $28 \times 10^{6}$ & 0 & 0 & 0 & 0 & 0.8 & $20 \%$ & 1.8 & $45 \%$ & 2.2 & $55 \%$ \\
\hline $14 \times 10^{6}$ & 0 & 0 & 0.6 & $15 \%$ & 0.8 & $20 \%$ & 1.6 & $40 \%$ & 1.8 & $45 \%$ \\
\hline $7 \times 10^{6}$ & 0 & 0 & 0 & 0 & 0 & 0 & 0.8 & $20 \%$ & 1 & $25 \%$ \\
\hline $3.5 \times 10^{6}$ & 0 & 0 & 0 & 0 & 0 & 0 & 0 & 0 & 0 & 0 \\
\hline $1.75 \times 10^{6}$ & 0 & 0 & 0 & 0 & 0 & 0 & 0 & 0 & 0 & 0 \\
\hline control & 0 & 0 & 0 & 0 & 0 & 0 & 0 & 0 & 0 & 0 \\
\hline
\end{tabular}

It was, also, noticed that the lowest mortality percentage occurred when treatment took placewith lowest concentration $\left(1.75 \times 10^{6}\right.$ conidia / 100ml). Mean while,the $10^{\text {th }}$ larval instar suffered $55 \%$ 
mortality, 25 days post treatment with the concentration $28 \times 10^{6}$ conidia $/ 100 \mathrm{ml}$, followed by 45 and $25 \%$ mortality for the $14 \times 10^{6}$ and $7 \times 10^{6}$ conidia $/ 100 \mathrm{ml}$ concentration, followed by $25 \%$ for the 0.25 $\mathrm{ml}$ concentration. Both $3.5 \times 10^{6}$ and $1.75 \times 10^{6}$ conidia / $100 \mathrm{ml}$ concentrations had no effect on $10^{\text {th }}$ larval instar 25days post treatment. No control larvae died during the bioassay experiments. It could be concluded that the first instar larvae were the highest susceptible to the B. bassiana treatments compared to thoseof elder instars. Regarding post-treatment mortalities, the lower cumulative mortality percentages occurred throughout the first five days post treatment.

Entomopathogenic fungi have been studied as potential biological control agents, but information on their natural incidence was limited in their studies. Verde et al., (2015) isolated strains of B. bassiana from symptomatic insects collected from dead palm trees in canary island, and their pathogenicity against different instars of $R$. ferrugineus was evaluated in the laboratory. They recorded $7 \%$ infected insects in Canary palms. In laboratory bioassays, larvae and adults were treated with a single isolate in two ways: spraying each insect with a conidial suspension or feeding them with fruit portions previously immersed in the same conidial suspension. At the end of the two trials, the mortality among treated larvae were 88 and $92 \%$, and the means of survival time were 10.4 and 11.8 days, being significantly shorter than those in the control, where no insect died during the trials. ElHindi, 2016 recorded significant difference in growth between treated and untreated larvae, the toxicity assay on larvae treated with the B. bassiana isolate, proved to be the most virulent to the larvae. The mortality of larvae was recorded for 6 days after treatment with spore suspension spraying (Hand Sprayer) by $3.4 \times 108$ spores $/ \mathrm{ml}$ of B.bassiana. The highest percentage mortality of the larvae reached $100 \%$ by 6 days after spraying with $B$. bassiana.

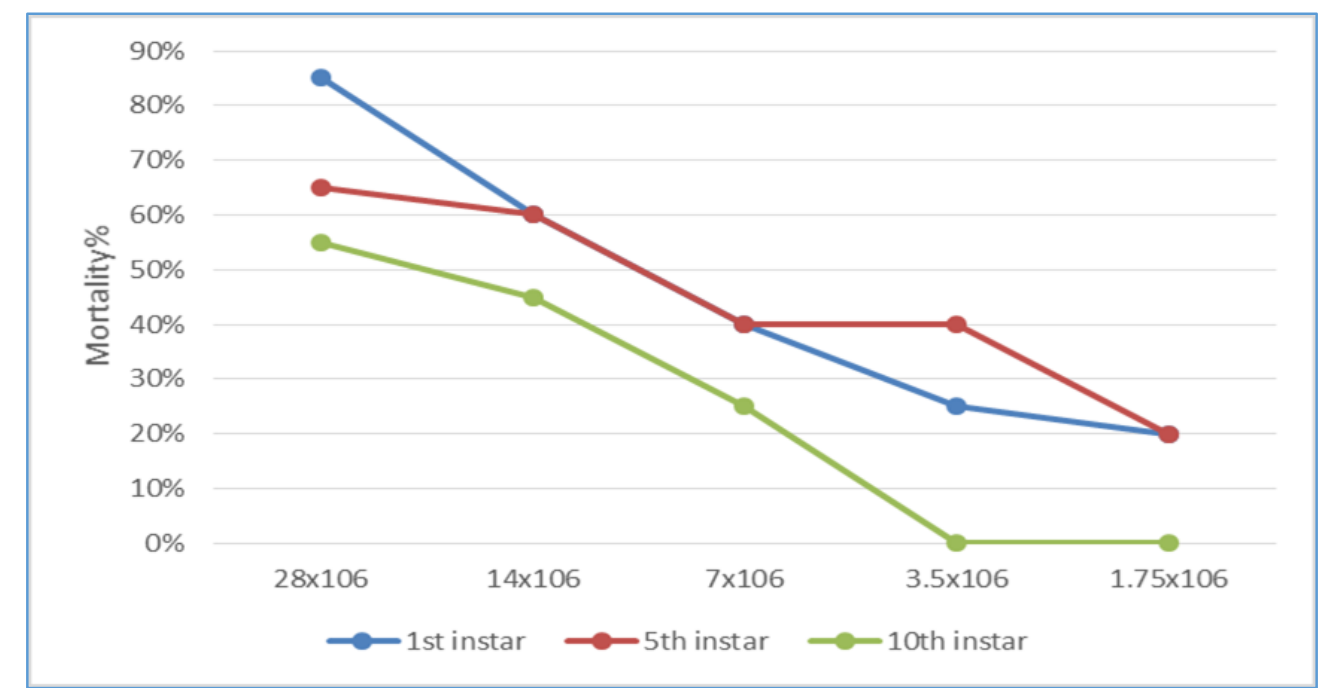

Fig. (4): Mean cumulative concentration mortality percentages among larvae of $R$. ferrugineus treated with conidial suspension $\left(28 \times 10^{6}\right.$ spores / $\left.100 \mathrm{ml}\right)$ of fungal isolate after 25 days of treatment.

Field application of Newfar (B. bassiana) on infested palm trees for RPW control.

Results are shown in (Table,5) depending upon the field observations(by naked eyes) on date palm trees which received Newfar(B.bassiana) treatment. These field observations were recorded 10, 15, 20 and 25 days after the first treatment.

Obtained results indicated that the infestation by $R$. ferrugineusbegan to stop 20days after treatment. As two trees proved recovered from infestation, the remaining three trees were found infested. 25days after treatments, one of the two infested palms proved recovered and, only, one palm tree continued as infested by RPW. Thus, indicating that the application method of $B$. bassiana for $R$. ferrugineus control caused $60 \%$ success $(3$ recovered trees from the 5 infested ones) 20days after treatment. While, after 25 days of treatment, this method proved $80 \%$ success
(4) of the 5 treated palms becomecompletelyrecovered).

In similar studies, El-Suftyet al., (2009) assayed the effect of field application of B. bassiana for control of RPW in United Arab Emirates. The authors used two methods for application of the entomopathogenic fungi in date palm plantations. Their results indicated that treatments caused 21.2 and $23.47 \%$ mortalities among adult population in 2005 and 2006, respectively. In another study, Sewifyet al., (2014) carried out a field experiment to evaluate integrated effect of baited aggregation pheromone traps and entomopathogenic fungus $B$. bassiana or insecticide for controlling $R$. ferrugineusin Ismailia Governorate, Egypt in 2008/09. Total mean reduction of RPW population caused by mass-trapping and the fungus $B$. bassiana or insecticide was 61.40 and $40.16 \%$, respectively. Also, considerable reduction of infested 
palm tree numbers was noticed in treated areas with the combinations compared with the control. Those were the least $(0.77$ and 0.82 palms $)$ at the combination of baited pheromone traps+the fungus and baited pheromone traps+insecticide, respectively and the highest (2.03 and 2.15 palms) occurred at the mass-trapping or insecticide alone, opposed to 3.73 palms in the control.

Table 5. Field treatments of date palm trees with Newfar (B. bassiana) at concentration (10 gm / liter of distilled water) at Al Kasasen region in the Ismailia Governorate in 2019.

\begin{tabular}{|c|c|c|c|c|c|}
\hline \multirow[b]{2}{*}{$\begin{array}{c}\text { Period after } \\
\text { treatment }\end{array}$} & \multicolumn{5}{|c|}{ Period after application / days } \\
\hline & $\begin{array}{l}1^{\text {st }} \text { Tree } \\
(5 \text { Holes })\end{array}$ & $\begin{array}{l}2^{\text {nd }} \text { Tree } \\
\text { (4 Holes) }\end{array}$ & $\begin{array}{l}3^{\text {rd }} \text { Tree } \\
\text { (6 Holes) }\end{array}$ & $\begin{array}{l}4^{\text {th }} \text { Tree } \\
(5 \text { Holes })\end{array}$ & $\begin{array}{l}5^{\text {th }} \text { Tree } \\
(6 \text { Holes })\end{array}$ \\
\hline 10 days & $x$ & $x$ & $x$ & $x$ & $x$ \\
\hline 15 days & $x$ & $x$ & $x$ & $x$ & $x$ \\
\hline 20 days & dry & $x$ & $x$ & $x$ & dry \\
\hline 25 days & & dry & $x$ & dry & \\
\hline
\end{tabular}

\section{Conclusion:}

Laboratory and field data obtained in this investigation proved that Beauvariabassianain both the commercial formulation (Newfar) or the fungal conidia are efficient against larvae and adults of the red palm weevil Rhynchophorusferrugineus. Accordingly, this entomopathogenic fungus is recommended to be considered when planning for RPW integrated control management program, taking into consideration that for older larval instars the increase of the applied concentration is need to insure satisfactory control.

\section{References}

Bakr E.M. 2005.A new software for measuring leaf area, and area damaged by tetranychusurticae Koch. J ApplEntomol, 129(3): 173-175.

Dembilio, Ó. and J. A. Jaques (2013). Biological control of Rhynchophorusferrugineus. In Colloqueméditerranéensur les ravageurs des palmiers, Nice, France. Association Française de Protection des Plantes (AFPP).

Dembilio, Ó. and J. A. Jaques (2015). Biology and management of red palm weevil. Sustainable pest management in date palm: Current status and emerging challenges, 13-35. Https // www. Research gate. Net / publication/ 288786774.

Dembilio, Ó.; E. Quesada-Moraga; C. SantiagoÁlvarez and J.A. Jaques(2010).Biocontrol potential of an indigenous strain of the entomopathogenic fungus Beauveriabassiana (Ascomycota; Hypocreales) against the red palm weevil, Rhynchophorusferrugineus (Coleoptera: Curculionidae). Journal of Invertebrate Pathology, 104: $214-221$.

El-Hindi, M. W. I. (2016).Isolation, molecular identification and lab evaluation of the entomopathogenic fungi; (Metarhiziumsp. and Beauveria sp.) against the Red Palm Weevil Rhynchophorusferrugineus. M.Sc. Thesis Fac. of Science. Islamic University-Gaza., Palestine.74: pp.
El Husseini, M.M. 2019.Efficacy of Beauveriabassiana (Balsamo) Vuillemin to red palm weevil, Rhyncophorusferrugineus Olivier larvae and adults (Coleoptera: Curculionidae) under laboratory conditions. Egyptian Journal of Biological Pest Control, 29(58):400-403.

El-Sufty, R.; S. A. Al-Awash; S. Al-Bgham; A. S. Shahdad and A. H. Al Bathra (2009). Pathogenicity of the fungus Beauveriabassiana (Bals.) Vuill to the red palm weevil, Rhynchophorusferrugineus (Oliv.) (Col.: Curculionidae), under laboratory and field conditions. Egyptian Journal of Biological Pest Control, 19(1):81-86.

EPPO (2010). EPPO Reporting Service. 2010/176First record of Rhynchophorusferrugineus in the USA, November 1, 2010. 22 pages.

Faleiro, J. R. (2006). A review of the issues and management of the red palm weevil Rhynchophorusferrugineus (Coleoptera: Rhynchophoridae) in coconut and date palm during the last one hundred years. International Journal of Tropical Insect Science, 26: 135 -154.

Hussain, A.; M. R. U. Haq; A. M. Al-Jabr and H. Y. Al-Ayied (2013). Managing invasive populations of red palm weevil: A worldwide perspective. Journal of Food Agriculture and Environment, 11: 456-463.

Jalinas, J.; B. Güerri-Agulló; R. W. Mankin; R. López-follana and L. V. LopezLlorca (2015). Acoustic assessment of Beauveriabassiana (Hypocreales: Clavicipitaceae) effects on (Coleoptera: Dryophthoridae) larval activity and mortality. Journal of Economic Entomology, 108: $444-453$.

Malik, M. A.; S. J. N. Ahmad; J. N. Ahmad; A. Abbasi; M. Sufyan and M. J. Arif (2019). Efficacy of Bacillus thuringiensis and Beauveriabassiana against Red palm weevil Rhynchophorusferrugineus Olivier (Coleoptera: Curculionidae): African Entomology, 27(2):386394. 
Manachini, B.; P. L. o. Bue; E. Peri and S. Colazza (2009). Potential effects of Bacillus thuringiensis against adults and older larvae of Rhynchophorusferrugineus. IOBC/wprs Bulletin, 45: 239-242.

Muhammad, Y.; W. Wakik; M. U. Ghazanfar; M. Abdul Qayyum; M. Tahir and G. O. Bedford (2019). Virulence of entomopathogenic fungi Beauveriabassiana and Metarhiziumanisopliae against red palm weevil, Rhynchophorusferrugineus

(Olivier).Entomological Research, 49 (2019) 312.

Murphy, S. T. and B. R. Briscoe (1999). The red palm weevil as an alien invasive: Biology and the prospect for biological control as component of IPM Bio control News and Information, 20:35-46.

Salama, H. S.; M. S. Foda; M. A. El-Bendary and A. Abdel-Razek (2004). Infection of red palm weevil, by spore-forming bacilli indigenous to its natural habitat in Egypt. Journal of Pest Science, 77: $27-31$.
Sewify, G. H.; M. H. Belal and M. Q. Saeed (2014). Using pheromone mass-trapping and the entomopathogenic fungus Beauveriabassiana in IPM programs for controlling the red palm weevil, Rhyncophorusferrugineus Olivier (Coleoptera: Rhynchophoridae). Egyptian Journal of Biological Pest Control, 24(1):197-202.

Singh, S. P. and P. Rethinam (2005). Trapping a major tactic of BEPM strategy of palm weevils. Cord, 21: $57-79$.

Verde, G. I. O.; L. Torta; V. Mondello; C. G. Caldarella; S. Burruano and V. Caleca (2015). Pathogenicity bioassays of isolates of Beauveriabassiana on Rhynchophorusferrugineus. Pest Management Science, 71(2):323-328. 47.

Wakil, W.; J. R. Faleiro and T. A. Miller (2015). Sustainable pest management in date palm: current status and emerging challenges. Springer International Publishing AG, Switzerland. 429 pp.

\section{أستخدام ال Beauveriabassianaكعصر مكافحة بيولوجية ضد برقات سوسة النخيل الحمراء تحت الظروف المختبرية وإلحقلية.

أجريت هذه الدراسة لفحص كفاءة المستحضر التجاري (نيوفار) لفطر . Beauveriabassiana(Bals.) Vuil و كذللك تركيزاته لسلالته المعزولة من جثث اليرقات الميتة لسوسة النخيل, ضد يرقات سوسة النخيل الحمراء Rhynchophorusferrugineus(Olivier) ـ أجريت تجارب

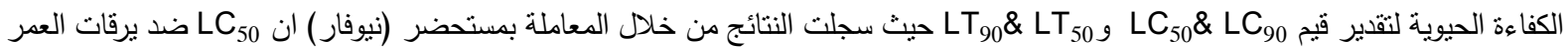

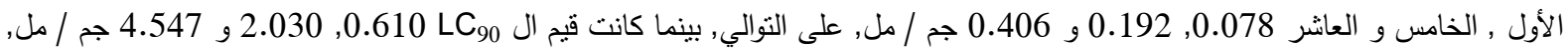

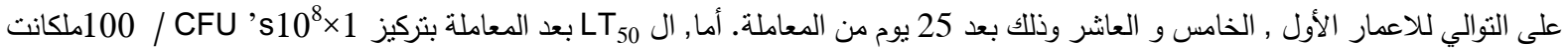

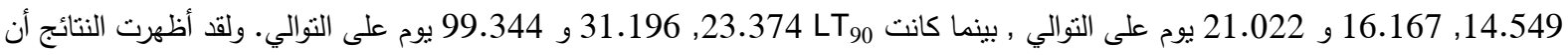

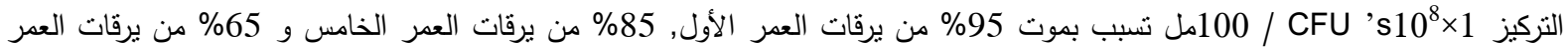

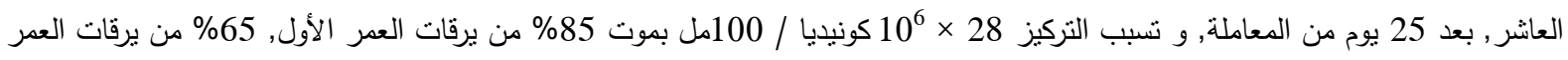

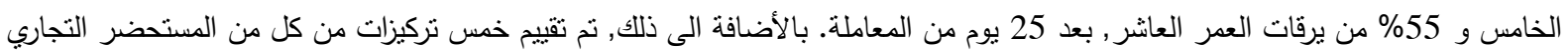
والعزلآت الكونيدية (CFU ’s10 ×1 / 100مل و 28 × $10^{8}$ كونيديا / 100مل) على العمر الأول, الخامس والعاشر من برقات سوسة النخيل الحمراء في المختبر والحقل. أظهرت النتائج إن الوفيات بين اليرقات المعاملة كانت تختلف بشكل ملحوظ عن الكنترول, حيث لم بسجل الئل أي موت

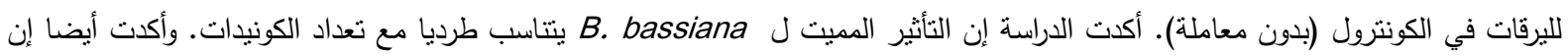

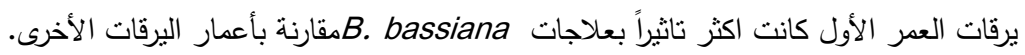

أوضحت الدراسة الميدانية إن أثنار النخيل المصابة التي تم حقنها بواسطة مستحضر نيوفار (B. bassiana) في موقع الأصابة بسوسة النخيل الحمراء تسببت فيشفائها من الاصابة بنسبة 80\% بعد انبه 25 يوماً من المعاملة. 